XIV.

\title{
AN INVESTIGATION OF THE BAYS OF THE SOUTHERN COAST OF NEW BRUNSWICK WITH A VIEW TO THEIR USE FOR OYSTER CULTURE.
}

\author{
Bì̀ J. W. Mavor, E. Horne Craigie, and J. D. Detweiler. \\ (With a Map showing Stations of Observation.)
}

\section{Introduction.}

The observations recorded in the present paper were made for the purpose of ascertaining what bays could be found on the southern coast of New Brunswick which supplied the conditions required for oyster culture. The investigation must be regarded as of a preliminary nature. Nearly all the observations were made between August 13 and 17 during two cruises with the motor-boat Prince of the Biological Station at St. Andrews. All the bays between the St. Croix river and St. John were visited, observations made on the temperature, salinity, and plankton, and the contents of dredgings determined. The stations at which this was done are listed below and their position marked accurately on the accompanying map. It was originally intended to include the Upper St. Croix river, Pegano cove, ,Oak bay, and Warwig ereek in the list of stations, but lack of time prevented this. In 1910, Mr. G. G. Copeland ${ }^{1}$ made hydrographic observations in these bays. His stations have been placed on the map and his data are given in our table of hydrographic observations. Mr. G. G. Copeland also made in the same year observations near our stations in Passamaquoddy bay. These observations also are given in tabular form. His temperatures, which were given in degrees Fahrenheit, have been reduced to the Centrigrade scale. In some cases records are given of dredgings made at the stations in previous years.

For the direction of the investigation and the methods used, Dr. J. W. Mavor is responsible, for the hydrographic observations, Mr. E. Horne Craigie, and for the dredging, Mr. J. D. Detweiler.

\section{A LIST OF THE ,STATTONS REFERRED TO IN THIS PAPER.}

Station 1. St. Croix river. Mr. Copeland's station 3.

* 2. Pagan's cove. Mr. Copeland's station 5B.

"3. Oak bay. Mr. Copeland's station 5A.

“ 4. Mouth of Warwig creek. Mr. Copeland's station 5D.

“5. Brandy cove, equally distant from sides and end.

"6. Chamcook harbour, between the bars, off an old weir, the highest hill west of Chamcook hill being between the two buildings of the Canadian Sardine Company's factory.

“ 7. Chamcook harbour, on a line between the factory and the opposite point, the lighthouse being in the centre of the height on the outer point.

1 G. G. Copeland, The Temperatures and Densities and Allied subjects of Passamaquoddy Bay and its environs. Their Bearing on the Oyster Industry. Contributions to Canadian Biology being studies from the Marine Biological Stations of Canada, 1906-10, Ottawa, 1912, pp. 281294.

$38 a-10$ 
Section 8. Bocabec river.
"9. Bocabec river, farther out.
"10. Digdeguash bay.
“ 11. Magaguadavic river, near the mouth.
“ 12. L'Etang harbour, off Indian point.
“ 13. I'Etang harbour, off Trainor's landing.
“ 14. Black's harbour, off Connors' factory.
“ 15. Black's harbour, head of bay, equidistant from end and sides.
"16. Beaver harbour.
“ 17. Lepreau, off point with Square House.
"18. Head of Musquash bay.
“ 19. Bay inside Mahogany island.
"20. Bay W.S.W. of Shag rocks (near St. John).

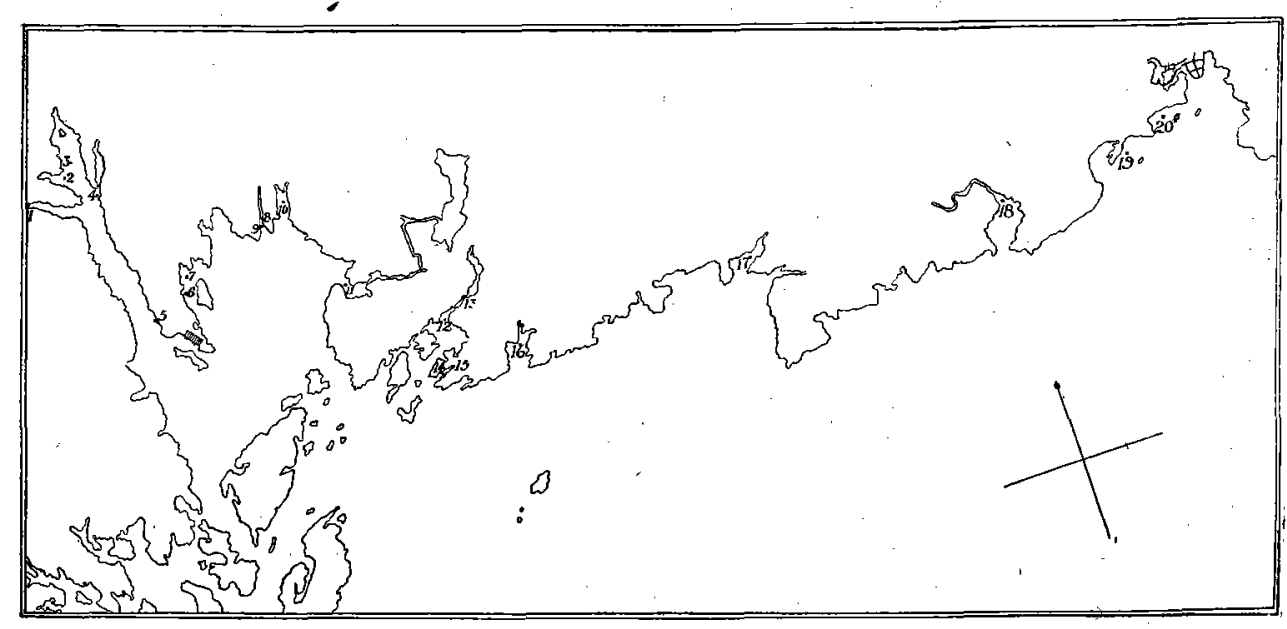

\section{HydRographic ObSERVATIONS.}

For taking the water samples a Pettersson-Nansen water bottle was used. This consists of an insulated metal cylinder, open at both ends, which slides vertically on two parallel brass rods. At the lower end of the brass rods a cap is fastened, which, when the cylinder is lowered, closes its lower end. The upper end of the cylinder is closed by a similar cap, which slides on the brass rods above. The apparatus is so constructed that it can be lowered down with the cylinder open and, when it arrives at the depth desired, can be closed by sending a weight down the sounding wire.

The temperatures were taken with a deep-sea reversing thermometer. In most cases the Richter reversing thermometer attached to the water bottle was used. (Laboratoire Hydrographique Kobenhavn, Preisliste, 1914, No. 75, Thermometer No. 164). In the other cases a revensing thermometer by Negretti and Zambra, No. 170664 , was used. In both of these thermometers the mercury column is narrow at a point just above the reservoir. By reversing the instrument at any required depth the mercury column is broken at the narrow part. The scale is marked on the glass so that the temperature at the time of reversing can be read off from the length of the broken off part of the mercury column. In the Richter thermometer an accessory thermometer was included in the same case in order that a correction for the expan- 
SESSIONAL PAPER No. 38a

sion of the mercury column due to the higher temperature of the air in which the reading was taken could be made. The Richter thermometer was reversed by the same messenger which reversed the water bottle. The Negretti and Zambra thermometer was used on a separate sounding line in a Maghnani case, which is reversed by a propeller which turned only when the thermometer was being raised.

The Richter thermometer had been tested by leaving it in the standard temperatures for fifteen minutes. It was found that readings made after the thermometer -had remained four minutes at a given depth differed from those obtained after fifteen minutes by less than one-tenth of a degree. It was also found that the correction for the expansion of the mercury column for the temperatures measured was about twenty-five thousandths of a degree. In the work, the thermometer was left at the required depth for four minutes and the correction neglected. Tests with the Negretti \& Zambra thermometer showed it to reach the temperature of the surrounding water after three minutes. In the above observations it was left at the depth recorded for three minutes.

The densities were determined with the hydrometer at room temperature and then corrected to read at $60^{\circ}$ F. or $15.56^{\circ} \mathrm{C}$. by Buchanan's diagram.

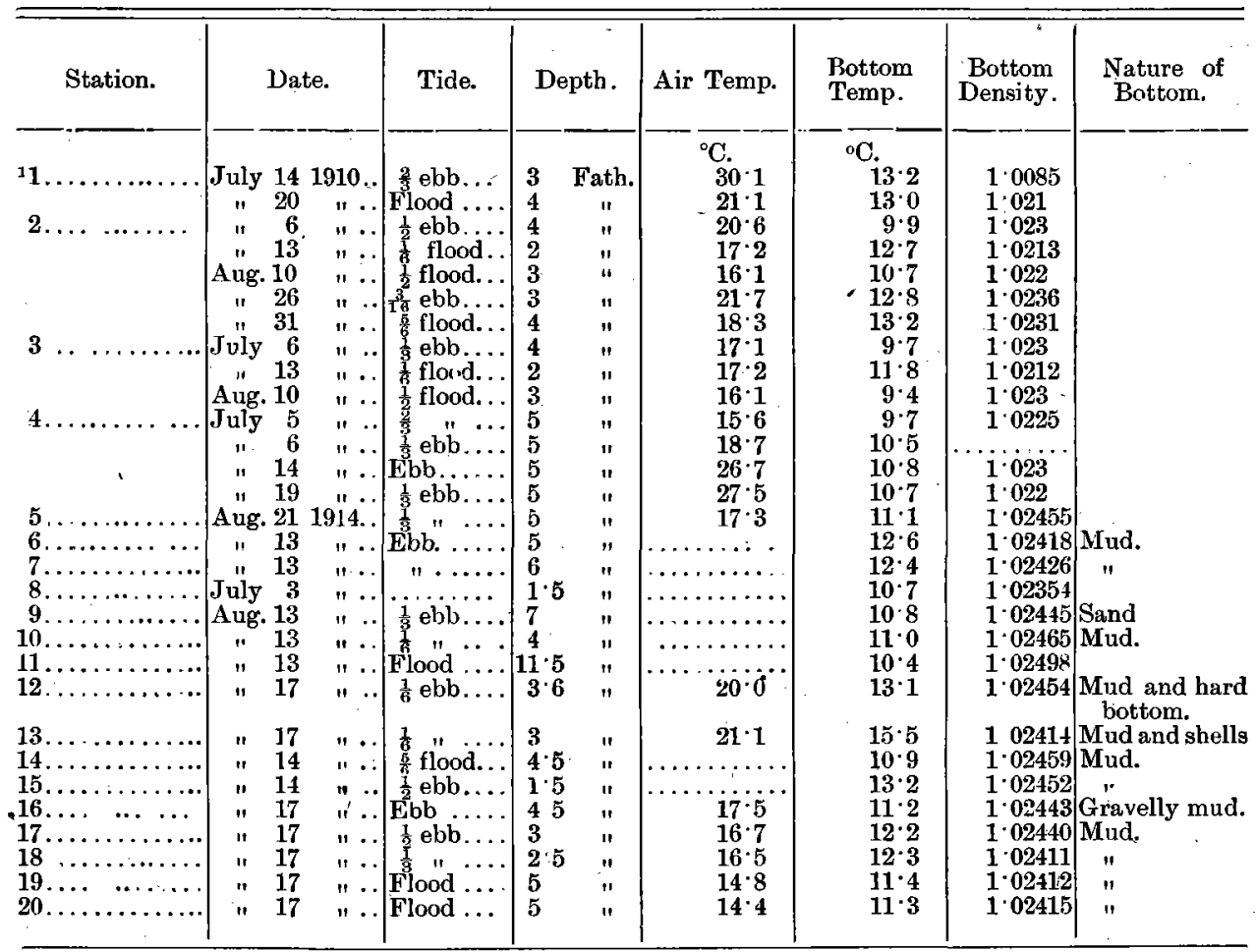

1 The data given under stations 1 to 4 are quoted from Mr. G. G. Copeland's tables. The readings on the Fahrenheit scale have been converted into the Centigrade scale.

It has not been found possible accurately to locate Mr. Copeland's stations, but where his observations have been taken very near some of the new stations, his tem-

1 J. Y. Buchanan. "Report on the Speoific Gravity of Samples of Ocean water, observed on board H. M. S. Challenger during the years 1873-76." Report of the Scientific Results of the exploring voyage of the Challenger, Physios and Chemistry, Vol. 1, 1884, Diagram 1.

$38 \mathrm{a}-10 \frac{1}{2}$ 
6 GEORGE V, A. 1916

peratures have been converted to the Centigrade scale, and are here given for comparison:-

\begin{tabular}{|c|c|c|c|c|c|c|c|c|c|}
\hline Copeland's station. & $\underset{\text { station. }}{\text { Near }}$ & \multicolumn{3}{|c|}{ Date. } & Tide. & \multicolumn{2}{|c|}{ Depth. } & Temp. & Density. \\
\hline $\begin{array}{l}26 \ldots \ldots \ldots \ldots \ldots \ldots \ldots \ldots \\
28 \ldots \ldots \ldots \ldots \ldots \ldots \ldots \\
\mathbf{3 3} \ldots \ldots \ldots \ldots, \ldots \ldots \ldots\end{array}$ & $\begin{array}{r}9 \\
10\end{array}$ & $\begin{array}{l}\text { July } \\
\text { Aug. } \\
\text { July } \\
\text { Aug. } \\
\text { " } \\
\text { " }\end{array}$ & $\begin{array}{r}26 \\
28 \\
26 \\
3 \\
3 \\
28\end{array}$ & $\begin{array}{r}1910 . . \\
" 1 \ldots \\
" \ldots . \\
" 1 \ldots \\
" 1 \ldots\end{array}$ & $\begin{array}{l}\frac{1}{9} \text { flood... } \\
\frac{1}{8} \text { ebb.... } \\
\frac{1}{2} \text { flood... } \\
\frac{1}{6} \text { ebb.... } \\
\text { Flood..... } \\
\frac{1}{2} \text { ebb.... }\end{array}$ & $\begin{array}{r}1 \\
2 \\
2 \\
3 \\
10 \\
8\end{array}$ & $\begin{array}{c}\text { Fath. } \\
" \\
" \\
" \\
"\end{array}$ & $\begin{array}{l}11 \cdot 2 \\
15 \cdot 6 \\
11 \cdot 7 \\
31 \cdot 2 \\
10 \cdot 7 \\
11 \cdot 9\end{array}$ & $\begin{array}{l}1 \cdot 022 \\
1 \cdot 0241 \\
1 \cdot 023 \\
1 \cdot 0225 \\
1 \cdot 0 \\
1 \cdot 0245\end{array}$ \\
\hline
\end{tabular}

\section{Dredgings.}

Dredgings were made at the following stations and the mollusca obtained determined. In some cases records of dredgings made previously without regard to this report are included:-

\section{Station 5-}

Date, July 6, 1913. Depth, 3 fathoms. Bottom, sawdust.

Dredgings-Thracia myopsis Beck, 1.

Leda tenuisulcata Stimpson, 1.

Tritia trivittata Adams, 1.

Cytherea conversea $\nabla$ erril, 2.

Station 6-

Date, July 11, 1913. Depth, 8 feet. Bottom, sand.

Dredgings-Yoldia limatula Say, several.

Station 10-

Date, August 16, 1913. Depth, 5 feet. Bottom, mud.

Dredgings-Yoldia limitula Say, 1.

Cardium pinnulatum Conrad, 1.

Chiton albus Montagu, 2.

Yoldia sapotilla Gould, several.

Bela sp., 1.

Station 12-

Date, August 16, 1914. Depth, $3 r_{3}^{2}$ fathoms. Bottom, mud and stones.

Dredgings-Polynices heros Say (small), 8.

Polynices trisereata Say, 1.

Siphonorbis pygmeus Gould, 4.

Venericardium borealis Conrad, 17.

Aporrhais occidentalis Sowerby (dead), 1.

Cylichnia alba Brown, 2.

Thyasira gouldii Phillippi, 3.

Station 13-

Bella pleurotomasia Adams, 1.

Date, August 17, 1914. Depth, 3 fathoms. Bottom, mud and shells.

Dredgings-Modiola modiolus Lamark, 1.

Pecten magellanicus Gmelin (dead), 1.

Tritonofusus stimpsoni Morch, 1.

Śaxicava rugosa Gould, a few.

Cardium pinnulatum Conrad, 2.

Doris sp., 4.

Chiton albus Montagu, 1. 
SESSIONAL PAPER No. 38a

Station 16-

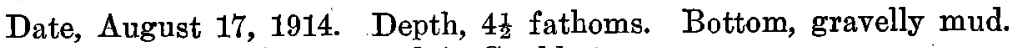

Dredgings-Astarte undata Gould, 1.

Tritia trivittala Adams, 1.

Venericardium borealis Conrad, 1.

Polynices heros Say, 4.

Polynices trisereata Say, 6.

Cardium pinnulatum Conrad, 2.

Cylichnia alba Brown, 6,

Utriculus.

Margarita, 3.

Leda tenuisulcata Stimpson, 1.

Cyclus (Cyprina) islandica Lamark, 1.

Station 17-

Date, August 17, 1914. Depth, 3 fathoms. Bottom, mud.

Dredgings-Polynices heros Say, 1.

Astarte sp. (small), 1.

Yoldia sapotilla Gould, 3.

Leda tenuisulcata Stimpson, 2.

Polynices triseriata Say, 9.

Cyclus (Cyprina) islandica Lamark, 1.

Lyonsia hyalina Conrad, 2. 